\title{
PENGARUH ANGGARAN BERBASIS KINERJA TERHADAP EFEKTIVITAS PENGENDALIAN ANGGARAN DI DINAS PENDAPATAN DAN PENGELOLAAN KEUANGAN DAN ASET DAERAH KABUPATEN BANDUNG BARAT
}

\author{
Dewi Kurniasari ${ }^{1}$, Dedeh Kurniasari ${ }^{2}$, M. Sandi Marta ${ }^{3}$ \\ Universitas Islam Negeri Sunan Gunung Djati Bandung \\ Email: \\ 11dewiq.sari74@yahoo.com, 2umudaibah@yahoo.com, ${ }^{3}$ sandymartha200732@gmail.com
}

\begin{abstract}
Research in budget control field has magnetized the interest of many researchers as a tool of development for many countries. This study examined the impact of Performance Based Budgeting on effectiveness of control budget. To achieve the above objective a survey of over 33 employee of DPKAD. Data was analyzed through descriptive and inferential statistical analysis. The results demonstrate that Performance Based Budgeting has positive impact on effectiveness of control budget.
\end{abstract}

Key words: Performance Based Budgeting and effectiveness of control budget

\section{PENDAHULUAN}

Reformasi Keuangan Negara ditandai dengan adanya penerapan Anggaran Berbasis Kinerja (ABK). Namun, pada implementasinya masih menimbulkan beberapa permasalahan. Salah satunya terkait pengendalian anggaran yang belum efektif. Hal ini memberikan implikasi yang cukup luas terhadap penyelenggara keuangan pemerintah baik dipusat maupun didaerah. Hal tersebut berdampak pada realisasi anggaran daerah yang belum tersalur secara maksimal.

Dinas Pendapatan dan Pengelolaan Keuangan dan Aset Daerah Kabupaten Bandung Barat telah menerapkan anggaran berbasis kinerja pada penyusunan anggarannya. Dengan diterapkannya anggaran berbasis kinerja tersebut diharapkan anggaran yang telah disusun dapat diwujudkan dengan baik sesuai dengan tujuan dan sasaran yang ingin dicapai.

Pentingnya dilakukannya penelitian ini adalah melihat dari fenomena yang terjadi di lingkungan Dinas Pendapatan dan Pengelolaan Keuangan dan Aset Daerah Kabupaten Bandung Barat dimana kinerja pemerintah yang saat ini banyak disoroti oleh masyarakat, Berdasarkan data LRA DPPKAD tahun 2014, dan 2015 secara keseluruhan belum menunjukkan indikasi adanya peningkatan realisasi anggaran dalam pelaksanaannya seperti yang diuraikan pada tabel dibawah ini: 
Tabel 1

Data Realisasi atau Penyerapan Anggaran

Dinas Pendapatan dan Pengelolaan Keuangan dan Aset Daerah Kabupaten Bandung Barat Tahun 2014

\begin{tabular}{|c|c|c|c|c|}
\hline \multirow{2}{*}{ Unit } & \multirow{2}{*}{$\begin{array}{c}\text { Anggaran } \\
\text { (RP) }\end{array}$} & \multicolumn{2}{|l|}{ Realisasi } & \multirow{2}{*}{ KET } \\
\hline & & Rp. & $\%$ & \\
\hline Belanja Pegawai & 1.019.329.361.239 & 966.921 .786 .048 & 94,86 & $\begin{array}{c}\text { Tidak } \\
\text { tercapai }\end{array}$ \\
\hline Belanja Barang & 388.399 .455 .585 & 344.738 .840 .393 .41 & 88,76 & $\begin{array}{c}\text { Tidak } \\
\text { tercapai }\end{array}$ \\
\hline Belanja Modal & 410.621 .824 .689 & 331.152.301.131 & 80,65 & $\begin{array}{c}\text { Tidak } \\
\text { tercapai }\end{array}$ \\
\hline
\end{tabular}

\begin{tabular}{llll} 
Jumlah $\quad 1.818 .350 .641 .513$ & $\mathbf{1 . 6 4 2 . 8 1 2 . 9 2 7 . 5 7 2 . 4 1} \quad 86,21$ \\
\hline
\end{tabular}

Sumber: Laporan Realisasi Anggaran DPPKAD Kab.Bandung Barat 2014

Tabel 2

Data Realisasi atau Penyerapan Anggaran

Dinas Pendapatan dan Pengelolaan Keuangan dan Aset Daerah Kabupaten Bandung Barat Tahun 2015

\begin{tabular}{ccccc}
\hline \multirow{2}{*}{ Unit } & Anggaran & \multicolumn{2}{c}{ Realisasi } & \multirow{2}{*}{ KET } \\
\cline { 3 - 4 } & (RP) & Rp. & \% & \\
\hline Belanja Pegawai & 1.136 .870 .715 .323 & 714.799 .223 .358 & 62,87 & $\begin{array}{c}\text { Tidak } \\
\text { tercapai }\end{array}$ \\
\hline Belanja Barang & 487.034 .412 .764 & 355.865 .464 .973 & 73,07 & $\begin{array}{c}\text { Tidak } \\
\text { tercapai }\end{array}$ \\
\hline Belanja Modal & 393.198 .404 .159 & 174.214 .774 .595 & 44,31 & $\begin{array}{c}\text { Tidak } \\
\text { tercapai }\end{array}$ \\
\hline Jumlah & $\mathbf{2 . 0 1 7 . 1 0 3 . 5 3 2 . 2 4 6}$ & $\mathbf{1 . 2 4 4 . 8 7 9 . 4 6 2 . 9 2 6}$ & $\mathbf{5 6 , 8 8}$ & \\
\hline
\end{tabular}

Sumber : Laporan Realisasi Anggaran DPPKAD Kab.Bandung Barat 2015.

Berdasarkan tabel data Laporan Realisasi Anggaran DPPKAD Kabupaten Bandung Barat diatas, Fenomena yang terjadi adalah berkaitan dengan penggunaan alokasi anggaran yang tidak terealisasikan dengan optimal sesuai dengan rencana alokasi anggaran yang telah direncanakan sebelumnya. Hal ini dapat dilihat dari selisih antara anggaran dengan realiasi anggaran belanja yang tahun 2014 dan tahun 2015. Anggaran yang diberikan oleh pemerintah untuk DPPKAD di setiap tahun nya mengalami kenaikan tetapi dalam penyerapannya belum optimal. Pada anggaran tahun 2014 sebesar Rp. 1.818.350.641.513.00 dengan realisasi anggaran Rp. 1.642.812.927.572.41 dengan presentase 86.21\%. Berbeda dengan tahun 2015 dimana anggaran unit telah dinaikan sebesar Rp. 2.017.103.532.246.00 tetapi dalam realisasi anggarannya mengalami penurunan yaitu sebesar Rp. 1.244.879.462.926.00 dengan 
presentase $56.88 \%$. Tanpa menjelaskan dan menyebutkan permasalahan dan hambatan apa yang terjadi yang menyebabkan ketidakrealisasikannya anggaran tersebut. Sehingga dalam hal ini Efektifitas Pengendalian Anggaran dalam pencapaian targetnya kurang baik dan harus adanya perbaikan akuntabilitas dan transparansi dalam menjelaskan proses dari hasil yang telah dicapai.

Berdasarkan perhitungan dan analisis kerja Dinas Pendapatan dan Pengelolaan Keuangan dan Aset Daerah Kabupaten Bandung Barat yang dilakukan dengan cara membandingkan rencana kinerja dengan tingkat realisasi, ternyata tingkat pencapaian atas kegiatan dan sasaran menunjukkan capaian kinerja pada tahun $201486.21 \%$ dan pada tahun 2015 adalah 56.88\%. Dalam hal ini terlihat jelas bahwa terjadi penurunan pada realisasi anggaran tahun 2014 dan 2015.

Selanjutnya, Sesuai dengan ketentuan penerapan anggaran berbasis kinerja yang dinyatakan dalam Peraturan Menteri Dalam Negeri (Permendagri) No 13 Tahun 2006 dan diubah lagi menjadi Permendagri No.59 Tahun 2007 tentang pedoman pengelolaan keuangan daerah. Dalam peraturan ini disebutkan tentang penyusunan Rencana Kerja dan Anggaran Satuan Kerja Perangkat Daerah (RKA-SKPD). Adanya RKA-SKPD ini berarti telah terpenuhinya kebutuhan tentang anggaran berbasis kinerja dan efektifitas pengendalian anggaran, dimana anggaran berbasis kinerja menuntut adanya output optimal atau pengeluaran yang dialokasikan sehingga setiap pengeluaran harus berorientasi atau bersifat ekonomi, efisien dan efektif di dalam pelaksanaannya dan mencapai suatu hasil (outcome). Kemudian melakukan penerpan anggaran berbasis kinerja tersebut, instansi dituntut untuk membuat standar kinerja pada setiap anggaran kegiatan sehingga jelas tindakan apa yang akan dilakukan, berapa biaya yang dibutuhkan, dan berupa hasil yang diperoleh (fokus pada hasil).

Artikel ini merupakan hasil penelitian yang mendiskusikan beberapa persoalan antara lain: pertama, tentang pengaruh dimensi efektif dalam anggaran berbasis terhadap efektifitas pengendalian anggaran; kedua, pengaruh dimensi efisiensi dalam anggaran berbasis kinerja terhadap efektifitas pengendalian anggaran; ketiga, pengaruh dimensi ekonomis dalam anggaran berbasis terhadap efektifitas pengendalian anggaran; dan keempat, pengaruh dimensi efektif, efisien, dan ekonomis dalam anggaran berbasis kinerja secara simultan terhadap efektifitas pengendalian anggaran di dinas pendapatan dan pengelolaan keuangan dan aset daerah kabupaten Bandung Barat.

\section{KAJIAN PUSTAKA \\ Anggaran Berbasis Kinerja}

Anggaran merupakan suatu rencana yang disusun secara sistematis dalam bentuk angka dan dinyatakan dalam unit moneter yang meliputi seluruh kegiatan Perusahaan untuk jangka waktu (periode tertentu dimasa yang akan datang). Anggaran merupakan kegiatan yang direpresentasikan dalam bentuk rencana perolehan pendapatan dan belanja dalam satuan moneter. Dalam bentuk yang balik sederhana, anggaran merupakan suatu dokumen yang menggambarkan kondisi keuangan dari suatu organisasi yang 
meliputi informasi mengenai pendapatan, belanja dan aktivitas (Halim, 2014).Anggaran merupakan rencana keuangan periodik yang disusun berdasarkan program-program yang telah disahkan dalam suatu instansi. Dalam perkembangannya, mekanisme birokrasi menjadi mekanisme yang sangat penting karena besarannya semakin meningkat. Perkembangan sistem penganggaran terjadi selaras dengan upaya pengalokasian sumber daya yang semakin lama semakin membaik dalam mengakomodasi berbagai penganggaran publik (Bastian, 2010).

Menurut Robinson dan Brumby (2005) mendefinikan performance budgeting sebagai prosedur dan mekanisme yang dimaksudkan untuk memperkuat kaitan antara dana yang disediakan untuk entitas sektor publik dengan outcome dan/atau output entitas tersebut melalui penggunaan informasi kinerja formal dalam pengambilan keputusan alokasi sumberdaya. Pengertian yang tidak jauh berbeda diberikan oleh Shah dan Shen (2007), yaitu suatu sistem penganggaran yang menyajikan tujuan dan sasaran untuk apa dana dibutuhkan, biaya dari program yang diusulkan dan kegiatan yang terkait untuk mencapai tujuan tersebut, serta output yang dihasilkan atau jasa yang diberikan pada setiap program.

Menurut Bastian (2010) pengertian anggaran berbasis adalah sistem penganggaran yang berorientasi pada output organisasi dan berkaitan sangat erat dengan visi, misi, serta rencana strategis organisasi. Performance budgeting mengalokasikan sumber daya ke program, bukan ke unit organisasi semata dan memakai pengukuran output (output measurement) sebagai indikator kinerja organisasi. Anggaran berbasis kinerja sebagai metode penganggaran bagi manajemen untuk mengaitkan setiap pendanaan yang dituangkan dalam kegiatan-kegiatan dengan keluaran dan hasil yang diharapkan termasuk efisiensi dalam pencapaian hasil dari keluaran tersebut. Keluaran dan hasil tersebut dituangkan dalam target kinerja pada setiap unit kerja (Halim, 2007).

Adapun indikator terkait ekonomis, efisiensi, dan efektifitas adalah sebagai berikut (Bastian, 2010):

1) Ekonomis

Indikator ekonomis merupakan indikator tentang penggunaan input. Pada dasarnya ekonomi lebih kepada input, efisiensi tentang input dan output, serta efektifitas yang berhubungan dengan output.

2) Efisiensi

Efisiensi merupakan hal terpenting, yaitu dengan rumusan: Suatu organisasi dianggap semakin efisien apabila rasio efisien cenderung diatas satu. Apabila hasil rasio lebih besar dari satu dibandingkan hasil rasio program yang sama, program tersebut bisa disebut lebih efisien. Karena itu efisien dapat dikembangkan dengan empat cara yakni pertama, dengan menaikkan output untuk input yang sama; kedua, dengan menaikkan output lebih besar dibandingkan proporsi peningkatan input; ketiga, dengan menurunkan input untuk output yang sama; dan keempat, dengan menurunkan input lebih besar dibandingkan proporsi gambaran output.

Input, sebagai penyebut, lebih sering dipertimbangkan sebagai faktor pengubah kebijakan orgnisasi sektor publik. 
3) Efektivitas

Efektivitas menunjukkan kesuksesan atau kegagalan dalam pencapaian tujuan. Ukuran efektivitas merupakan refleksi output. Tujuan-tujuan organisasi harus spesifik, detail, dan terukur. Dalam rangka mencapai tujuan itu, organisasi sektor publik sering kali tidak memperhatikan biaya yang dikeluarkan. Hal seperti itu bisa terjadi, apabila efisiensi biaya bukan merupakan salah satu dari indikator hasil.

\section{Efektifitas Pengendalian Anggaran}

\section{Menurut Mardiasmo} mengungkapkan efektifitas adalah ukuran berhasil tidaknya suatu organisasi mencapai tujuannya. Apabila suatu organisasi mencapai tujuan, maka organisasi tersebut dikatakan telah berjalan dengan efektif. Hal terpenting yang perlu dicatat adalah bahwa efektifitas tidak menyatakan tentang besar biaya yang telah dikeluarkan untuk mencapai tujuan tersebut. Biaya boleh jadi melebihi apa yang telah dianggarkan, boleh jadi dua kali lebih besar atau bahkan tiga kali lebih besar daripada yang telah dianggarkan. Efektifitas hanya melihat apakah suatu program atau kegiatan telah mencapai tujuan yang telah ditetapkan.Efektifitas merupakan hasil prestasi yang dicapai suatu organisasi (Maman Ukas, 2004). Efektifitas sebagai suatu yang ada efeknya (keadaan berpengaruh), dapat membawa hasil, berhasil guna (tindakan) serta dapat berarti mulai berlaku tentang undang-undang peraturan (Alwi, Hasan,2007). Pengertian efektifitas yaitu penilaian yang dibuat sehubungan dengan prestasi individu, kelompok, dan organisasi. Makin dekat prestasi mereka terhadap prestasi yang diharapkan (standar), maka makin efektif menilai mereka (Gibson,et al, 1995).

Beberapa pandangan Gibson (1995) tentang efektivitas pertama, Efektivitas individu yang menekankan pada: (1) hasil karya pegawai atau anggota tertentu dari organisasi, dan (2) prestasi kerja individu dinilai secara rutin lewat proses evaluasi hasil karya yang merupakan dasar bagi kenaikan gaji, promosi dan imbalan yang lain yang tersedia dalam organisasi. Kedua, Efektivitas kelompok yang menekankan pada: (1) bekerja secara bersama-sama dalam kelompok, dan (2) hasil yang dicapai jumlah kontribusi dari semua anggota. Ketiga, Efektivitas organisasi terdiri dari individu dari kelompok yang menekankan pada hasil karya yang lebih tinggi tingkatnya, dari pada jumlah hasil karya tiap-tiap bagiannya.

Menurut Jones dan Pendlebury (2000) menjelaskan pengendalian anggaran berhubungan dengan upaya yang dilakukan agar pengeluaran actual sejalan dengan jumlah yang dianggarkan dan bahwa tujuan dan tingkat aktivitas yang dicantumkan dalam anggaran tercapai. Menurut Akhmad Syakhroza (2004) mengatakan pencapaian target anggaran memainkan peranan penting karena anggaran menggambarkan standar efektifitas dan efisiensi. Anggaran menggambarkan standar efektifitas karena memuat suatu set pengeluaran yang diinginkan dan standar efisiensi karena anggaran memerinci masukan yang diperlukan untuk menghasilkan pengeluaran yang diinginkan. Dengan demikian, efektifitas pengendalian dalam penganggaran adalah 
dicapainya realisasi pengeluaran anggaran yang sesuai dengan rencana.

Sistem anggaran yang dapat diandalkan dan efektif menurut Umar (2003) mempunyai karakteristik tertentu yaitu:

1. Akurat. Informasi tentang hasil prestasi kerja harus akurat. Mengevaluasi ketepatan yang diterima merupakan salah satu pengendalian paling penting.

2. Tepat waktu. Informasi hendaknya segera dimanfaatkan untuk mengambil tindakan yang tepat terhadap suatu masalah agar dihasilkan perbaikan.

3. Objektif dan komprehensif. Informasi yang digunakan untuk pengawasan harus dapat dipahami dan dianggap objektif. Sistem informasi yang sulit dipahami akan mengakibatkan kesalahan yang sebenarnya tidak perlu terjadi.

4. Dipusatkan pada titik pengendalian strategis. Pengendalian hendaknya dipusatkan pada area dimana kemungkinan terjadinya penyimpangan relatif banyak, juga pada area dimana tindakan koreksi dilaksanakan tepat waktu serta tempatnya sehingga efektif.

\section{Anggaran Berbasis Kinerja dan Efektifitas Pengendalian Anggaran}

Mardiasmo (2002) mengemukakan efektifitas pengendalian adalah ukuran berhasil tidaknya suatu organisasi mencapai tujuannya. Apabila suatu organisasi mencapai tujuan, maka organisasi tersebut dikatakan telah berjalan dengan efektif. Hal terpenting yang perlu dicatat adalah bahwa efektifitas tidak menyatakan tentang besar biaya yang telah dikeluarkan untuk mencapai tujuan tersebut. Biaya boleh jadi melebihi apa yang telah dianggarkan, boleh jadi dua kali lebih besar atau bahkan tiga kali lebih besar daripada yang telah dianggarkan. Efektifitas hanya melihat apakah suatu program atau kegiatan telah mencapai tujuan yang telah ditetapkan.

Menurut Mahmudi (2015) efektifitas terkait dengan hubungan antara hasil yang diharapkan dengan hasil yang sesungguhnya dicapai. Efektifitas merupakan hubungan antara output dengan tujuan. Semakin besar kontribusi output terhadap pencapaian tujuan, maka semakin efektif organisasi, program, atau kegiatan. Jika ekonomi berfokus pada input dan efisien pada output atau proses, maka efektifitas berfokus pada outcome (hasil). Suatu organisasi, program, atau kegiatan dinilai efektif apabila output yang dihasilkan bisa memenuhi tujuan yang diharapkan, atau dikatakan spending wisely.

Pengendalian menurut Mardiasmo (2002) yaitu : "mekanisme yang dilakukan oleh eksekutif (pemerintah daerah) untuk menjamin dilaksanakannya sistem dan kebijakan manajemen sehingga tujuan organisasi dapat tercapai". Pengendalian sebagai suatu proses pengamatan dari pada pelaksanaan seluruh kegiatan organisasi untuk menjamin agar semua pekerjaan yang sedang dilakukan berjalan sesuai dengan rencana yang telah ditetapkan.

Selanjutnya untuk meningkatkan efektifitas pengendalian anggaran maka sangat diperlu diperhatikan sistem anggaran yang dijalankan suatu instansi dan organisasi. Anggaran berbasis kinerja merupakan salah system untuk mengefektifkan, efesienkan serta mengekonomiskan suatu anggaran. Performance-based budgeting bertujuan 
untuk meningkatkan efisiensi dan efektifitas pengeluaran publik dengan mengaitkan pendanaan organisasi sektor publik dengan hasil yang dicapai dengan penggunaan informasi kinerja secara sistematik. Teori anggaran berbasis kinerja (performance based budgeting), yang dikemukakan oleh Bastian (2010) yang menyatakan bahwa "Anggaran berbasis kinerja adalah sistem penganggaran yang berorientasi pada output organisasi dan berkaitan sangat erat dengan visi, misi serta rencana strategis organisasi. Dimana performance budgeting mengalokasikan sumber daya ke program, bukan ke unit organisasi semata dan memakai pengukuran output(output measurement) sebagai indikator kinerja organisasi. Lebih jauh, pengkaitan biaya dengan output organisasi merupakan bagian integral dalam berkas anggarannya. Dengan kata lain, performance budgeting adalah teknik penyusunan anggaran berdasarkan pertimbangan beban kerja (work load) dan biaya unit (unit cost) dari setiap kegiatan yang terstruktur.

Pengukuran output (output measerement) yang dikaitkan dengan biaya adalah mengukura tingkat efisiensi dan efektivitas. Hal ini sekaligus merupakan alat untuk dapat menjalankan prinsip akuntabilitas, karena yang diterima oleh masyarakat pada akhirnya adalah output dari suatau proses kegiatan organisasi.

Kerangka pemikiran yang digunakan untuk merumuskan hipotesis dalam penelitian ini adalah sebagai berikut:

\section{Gambar 1}

Skema Kerangka Pemikiran



Sumber: Diolah oleh Peneliti Tahun 2016

Atas dasar kerangka berpikir yang telah dijelaskan sebelumnya, maka dirumuskan hipotesis asosiatif penelitian, yakni : Volume 2, Nomor 2, Oktober 2017
Hipotesis H1: Dimensi efektif dalam anggaran berbasis kinerja berpengaruh positif terhadap efektifitas PUBLISIA (Jurnal Ilmu Administrasi Publik) | 77 
pengendalian anggaran di DPPKAD Kabupaten Bandung Barat.

Hipotesis H2: Dimensi efisien dalam anggaran berbasis kinerja berpengaruh positif terhadap efektifitas pengendalian anggaran di DPPKAD Kabupaten Bandung Barat.

Hipotesis H3: Dimensi ekonomis dalam anggaran berbasis kinerja berpengaruh positif terhadap efektifitas pengendalian anggaran di DPPKAD Kabupaten Bandung Barat.

Hipotesis H4: Dimensi efektif, efisien, dan ekonomis dalam anggaran berbasis kinerja secara simultan berpengaruh positif terhadap efektifitas pengendalian anggaran di DPPKAD Kabupaten Bandung Barat.

\section{METODOLOGI}

\section{Metode}

Pendekatan yang digunakan dalam penelitian ini adalah pendekatan kuantitatif, menurut Arikunto (2006) pendekatan kuantitatif adalah pendekatan penelitian yang banyak dituntut menguakan angka, mulai dari pengumpulan data, penafsiran terhadap data tersebut, serta penampilan hasilnya. Jenis penelitian yang digunakan dalam penelitian ini yaitu metode eksplanasi dimana penelitian ini menjelaskan kedudukan variabel-variabel yang diteliti serta hubungan antara satu variabel dengan variabel yang lain. Singarimbun dan Efendi (2003) metode eksplanasi yaitu: “Apabila peneliti menjelaskan hubungan atau pengaruh kausal antara variabel-variabel melalui pengujian hipotesis maka dinamakan penelitian penjelasan (Eksplanatory Research)." Dengan penelitian ini akan dapat dibangun suatau teori yang dapat berfungsi untuk menjelaskan, meramalkan, dan mengontrol suatu gejala (Sugiyono, 2013).

\section{Populasi dan Sampel}

Populasi dalam penelitian ini adalah seluruh pegawai di Dinas Pendapatan dan Pengelolaan Keuangan dan Aset Daerah Kabupaten Bandung Barat yang berjumlah 33 orang. Penentuan jumlah sampel yang digunakan oleh penulis dalam penelitian ini, berdasarkan pada ketentuan yang dikemukakan oleh Arikunto (1993) Apabila populasi kurang dari 100 orang, lebih baik diambil semua populasi untuk dijadikan sampel sehingga penelitiannya merupakan penelitian populasi. Selajutnya jika populasinya besar di atas 100 orang maka diambil $10-15 \%$ atau $15-20 \%$ atau lebih dari itu. Teknik pengambilan sample dalam penelitian ini menggunakan sampling jenu. Menurut Sugiyono (2013) Sampling jenuh adalah teknik penentuan sampel bila semua anggota populasi digunakan sebagai sample. Istilah lain dari sampel jenuh adalah sensus."

\section{Pengukuran Variable}

Pengujian instrument penelitian dalam variable menggunakan beberapa uji di antara uji validitas dan uji reliabilitas. Pengujian validitas memiliki standar cut off point harus lebih dari 0.30 (Hair et al: 1989), Sedangkan pengujian reliabilitas memiliki standar cut off 
point harus lebih dari 0.60 (Nunnally dalam Ghozali, 2005).

\section{Anggaran berbasis kinerja}

Anggaran berbasis kinerja memiliki dimensi yang akan di uji pengaruhnya dimensi tersebut terhadap efektifitas pengendalian dimensi tersebut diantaranya ekonomis, efisiensi, dan efektifitas adalah sebagai berikut (Bastian, 2010:61): dimensi ekonomis akan diukur dengan 6 indikator, dimensi efisiensi diukur dengan 6 indikator, sedangkan dimensi efektivitas diukur dengan 5 indikator, indikiator-indikator tersebut dikembangkan dari Bastian (2010:61).
Efektifitas Pengendalian Anggaran

Pengukuran efektifitas pengendalian anggaran dalam penelitian ini menggunakan 6 indikator yang dikembangkan oleh Mardiasmo (2009: 3) yang menyatakan bahwa efektifitas pengendalian anggaran memiliki dua dimensi dan masing dimensi di ukur dengan 3 indikator.

\section{HASIL DAN PEMBAHASAN}

Hasil Pengujian Validitas

Hasil perhitungan validitas untuk keseluruhan butir pertanyaan pada variable anggaran berbasis kinerja dan efektifitas pengendalian anggaran dapat dijelaskan sebagai berikut:

Tabel 3

Hasil Pengujian Validitas

\begin{tabular}{ccccc}
\hline Variabel & Item & r Hitung & r Tabel & Keterangan \\
& & & & \\
(1) & $(2)$ & $(3)$ & $(4)$ & $(5)$ \\
Efektif (X1) & 1 & 0,723 & 0,3 & Valid \\
& 2 & 0,778 & 0,3 & Valid \\
& 3 & 0,443 & 0,3 & Valid \\
& 4 & 0,682 & 0,3 & Valid \\
& 5 & 0,536 & 0,3 & Valid \\
Efisien (X2) & 6 & 0,535 & 0,3 & Valid \\
& 7 & 0,713 & 0,3 & Valid \\
& 8 & 0,701 & 0,3 & Valid \\
& 9 & 0,512 & 0,3 & Valid \\
& 10 & 0,680 & 0,3 & Valid \\
Ekonomis (X3) & 11 & 0,527 & 0,3 & Valid \\
& 12 & 0,641 & 0,3 & Valid \\
& 13 & 0,593 & 0,3 & Valid \\
& 14 & 0,604 & 0,3 & Valid \\
& 15 & 0,702 & 0,3 & Valid \\
& 16 & 0,750 & 0,3 & Valid \\
& 17 & 0,688 & 0,3 & Valid \\
& 18 & 0,370 & 0,3 & Valid \\
Efektivitas Pengendalian & 19 & 0,387 & 0,3 & Valid \\
Anggaran & 20 & 0,363 & 0,3 & Valid \\
(Y) & 21 & 0,840 & 0,3 & Valid \\
& 22 & 0,877 & 0,3 & Valid \\
& 23 & 0,841 & 0,3 & Valid \\
\hline
\end{tabular}

Sumber: Hasil Perhitungan Validitas 2016 
Berdasarkan hasil analisis didapat nilai korelasi item-item yang nilainya lebih dari 0,3 sehingga dapat disimpulkan bahwa butir instrumen penelitian Anggaran Berbasis Kinerja dan Efektifitas Pengendalian Anggaran tersebut valid.

\section{Hasil Uji Reliabilitas}

Uji reliabilitas dilakukan untuk mengetahui apakah hasil pengukuran tetap kosisten apabila dilakukan pengukuran secara berulang kali terhadap gejala yang sama dengan menggunakan suatu alat ukur yang sama (Cooper \& Schindler, 2003). Uji reabilitas yang digunakan pada penelitian ini menggunakan uji konsistensi internal (internal consistency) dengan menggunakan nilai cronbach alpha. Konsistensi internal suatu alat ukur menunjukkan homogenitas item-item pertanyaan dalam mengukur suatu konsep. Dalam mengukur suatu konsep yang sama, maka item-item penelitian tersebut harus berkorelasi secara positif antara satu dengan lainnya. Nilai rule of thumb yang dapat dijadikan ukuran yaitu bahwa koefisien > 0,60, nilai tersebut dapat diterima (Nunnally dalam Ghozali, 2005) hasil uji reabilitas dengan menggunakan cronbach alpha terhadap item-item pertanyaan ditunjukan dalam tabel 4.

Tabel 4.

Hasil Uji Reliabilitas

\begin{tabular}{cccc}
\hline Item & $\begin{array}{c}\text { Nilai Cronbach } \\
\text { Alpha }\end{array}$ & $\begin{array}{c}\mathrm{r} \\
\text { kriteria }\end{array}$ & Keterangan \\
\hline Efektif & 0,671 & 0.60 & Reliabilitas baik \\
Efesien & 0,681 & 0.60 & Reliabilitas baik \\
$\begin{array}{c}\text { Ekonomis } \\
\text { Efektifitas pengendalian } \\
\text { anggaran }\end{array}$ & 0,678 & 0.60 & Reliabilitas baik \\
\hline
\end{tabular}

Sumber: data yang telah diolah, 2016

Berdasarkan hasil uji reliabilitas bahwa setiap variabel yang digunakan dalam penelitian ini dinyatakan reliabel. Pernyataan tersebut didasarkan dari hasil uji reliabilitas penelitian diperoleh Cornbach's Alpha lebih besar apabila dibandingkan dengan $r$ kriteria, yaitu 0,60 dengan demikian secara keseluruhan variabel penelitian menunjukan bahwa konsistensi internal item-item pertanyaan dalam kuesioner dapat diterima.

\section{Regresi Linier Berganda}

Analisis regresi linier berganda adalah regresi dimana variabel terikatnya Efektivitas Pengendalian Anggaran (Y) dihubungkan atau dijelaskan dengan lebih dari satu variabel $X$ yaitu Efektif, Efisien, dan Ekonomis. Namun hubungan ini masih menunjukkan diagram hubungan yang linear. Berdasarkan hasil pengolahan data dengan bantuan software SPSS 21. diperoleh hasil regresi sebagai berikut: 


\section{Tabel 5}

Hasil Pengujian Regresi Berganda

\begin{tabular}{rlrrrrr}
\hline \multicolumn{7}{c}{ Coefficients $^{\mathrm{a}}$} \\
\hline Model & \multicolumn{7}{c}{$\begin{array}{c}\text { Unstandardized } \\
\text { Coefficients }\end{array}$} & $\begin{array}{c}\text { Standardized } \\
\text { Coefficients } \\
\end{array}$ & \multicolumn{7}{c}{ B } & Std. Error & B & Sig. \\
1 & (Constant) &, 078 &, 125 & &, 625 &, 537 \\
& Efektif &, 192 &, 077 &, 186 & 2,503 &, 018 \\
& Efisien &, 370 &, 122 &, 387 & 3,031 &, 005 \\
& Ekonomis &, 422 &, 111 &, 436 & 3,806 &, 001
\end{tabular}

a. Dependent Variable: efektivitas pengendalian anggaran

Sumber: Hasil Pengolahan Menggunakan Program SPSS 21

Berdasarkan hasil olahan data menggunakan program SPSS 21. Tabel $4.10 \mathrm{di}$ atas maka dapat disusun estimasi model regresi linear berganda sebagai berikut:

$$
\begin{gathered}
Y=\beta_{0}+\beta_{1} x_{1}+\beta_{2} x_{2}+\beta_{3} x_{3}+\varepsilon_{i} \\
Y=0,078+0,192 x_{1}+0,370 x_{2}+0,422 x_{3} \\
+a_{i}
\end{gathered}
$$

Artinya :

1. Konstanta sebesar 0,078 artinya: “ jika dimensi efektif yang telah ditetapkan ( $\left.X_{1}\right)$, efesien $\left(X_{2}\right)$ dan ekonomis $\left(X_{3}\right)$ nilainya adalah 0 , maka efektivitas pengendalian anggaran $(\mathrm{Y}$ ) nilainya adalah $0,078 "$.

2. Koefisien regresi dimensi efektif $\left(X_{1}\right)$ sebesar 0,192 artinya jika variabel independen lain nilainya tetap dan efektif mengalami kenaikan 1\%, maka efektivitas pengendalian anggaran akan mengalami kenaikan sebesar 0,192 . Koefisien dalam regresi variabel efektif ( $\mathrm{X}_{1}$ ) bernilai positif artinya terjadi hubungan positif antara efektif dengan efektivitas pengendalian anggaran. Apabila efektif meningkat maka efektivitas pengendalian anggaranpun akan ikut meningkat.

3. Koefisien regresi dimensi efesien $\left(X_{2}\right)$ sebesar 0,370 artinya jika variabel independen lain nilainya tetap dan efesien mengalami kenaikan 1\%, maka efektivitas pengendalian anggaran akan mengalami kenaikan 0,370 . Koefisien regresi variabel efesien $\left(X_{2}\right)$ bernilai positif artinya terjadi hubungan positif antara efesien dengan efektivitas pengendalian anggaran, dimana apabila efesien meningkat maka efektivitas pengendalian anggaran akan meningkat pula.

4. Koefisien regresi dimensi ekonomis $\left(X_{3}\right)$ sebesar 0,422 artinya jika variabel independen lain nilainya tetap dan ekonomis mengalami kenaikan $1 \%$, maka efektivitas pengendalian anggaran akan mengalami kenaikan 0,422. Koefisien regresi variabel ekonomis $\left(X_{3}\right)$ bernilai positif artinya terjadi hubungan positif antara ekonomis dengan efektivitas pengendalian anggaran, dimana apabila ekonomis meningkat maka efektivitas pengendalian anggaran akan meningkat pula.

\section{Uji Signifikan Pengaruh Parsial (Uji t)}

Uji parsial atau biasanya lebih dikenal uji $\mathrm{t}$ adalah suatu uji yang dilakukan untuk mengetahui pengaruh dimensi Efektif, Efisien, Ekonomis terhadap efektivitas pengendalian anggaran secara terpisah/masingmasing/satu persatu. Uji $t$ diolah dengan program SPSS 21 sebagai berikut: 
Berdasarkan table di atas dapat disimpulkan bahwa pengaruh efektif dalam anggaran berbasis kinerja berpengaruh positif terhadap efektifitas pengendalian anggaran karena terlihat dari $t_{\text {hitung }}(2,503)>t_{\text {tabel }}(2,042)$ dan taraf signifikansi $0.018<0.05$ maka $\mathrm{H}_{0}$ ditolak, hal ini berarti efektif berpengaruh secara parsial terhadap efektivitas pengendalian anggaran pada DPPKAD Kabupaten Bandung Barat.

Selain itu pengaruh efesien dalam anggaran berbasis kinerja berpengaruh positif terhadap efektifitas pengendalian anggaran karena thitung $(3,031)>t_{\text {tabel }}(2,042)$ dan pada taraf signifikansi $0.005<0.05$ maka $\mathrm{H}_{0}$ ditolak, hal ini berarti efisien berpengaruh secara parsial terhadap efektivitas pengendalian anggaran pada DPPKAD Kabupaten Bandung barat.

Dimensi terakhir ekonomis dalam anggaran berbasis kinerja berpengaruh positif terhadap efektifitas pengendalian anggaran karena $t_{\text {hitung }}(3,806)>t_{\text {tabel }}(2,042)$ pada taraf signifikansi $0.001<0.05$ maka $\mathrm{H}_{0}$ ditolak, hal ini berarti ekonomis berpengaruh secara parsial terhadap efektivitas pengendalian anggaran pada DPPKAD Kabupaten Bandung Barat.

\section{Uji Signifikan Pengaruh simultan (Uji F)}

Berdasarkan hasil uji $\mathrm{F}$, data berikut dapat menggambarkan:

Tabel 6

Hasil Uji-F

\begin{tabular}{llrrrrr}
\hline \multicolumn{6}{c}{ ANOVA $^{\mathrm{a}}$} \\
\hline Model & \multicolumn{1}{c}{$\begin{array}{c}\text { Sum of } \\
\text { Squares }\end{array}$} & $\mathrm{df}$ & $\begin{array}{c}\text { Mean } \\
\text { Square }\end{array}$ & $\mathrm{F}$ & Sig. \\
& Regressio & 6,013 & 3 & 2,004 & 321,772 & \multirow{2}{*}{$000^{\mathrm{b}}$} \\
$\mathrm{n}$ & & & & & \\
& Residual &, 181 & 29 &, 006 & & \\
& Total & 6,194 & 32 & & &
\end{tabular}
A. Dependent variable: efektivitas pengendalian anggaran
B. Predictors: (constant), ekonomis, efektif, efisien

Dari hasil uji $\mathrm{f}$ dapat disimpulkan bahwa $F_{\text {hitung }}(321,772)>\mathrm{F}_{\text {tabel }}(2,93)$ dan berdasarkan uji taraf signifikansi $0.000<0.05$ maka $\mathrm{H}_{0}$ ditolak dan $\mathrm{Ha}$ diterima, hal ini berarti efektif, efisien, dan ekonomis dalam anggaran berbasis kinerja berpengaruh secara simultan terhadap efektivitas pengendalian anggaran pada Dinas Pendapatan dan Pengelolaan Keuangan dan Aset Daerah (DPPKAD) Kabupaten Bandung Barat.

\section{Uji Koefisien Determinasi}

Analisis determinasi digunakan untuk menunjukkan seberapa besar efektif, efisien, dan ekonomis meramalkan efektivitas pengendalian anggran pada Dinas pendapatan dan Pengelolaan Keuangan dan Aset daerah Kabupaten Bandung barat. Hasil perhitungan koefisien determinasi dapat dilihat pada tabel dibawah ini : 
Tabel 6

Analisis Koefisien Determinasi

\begin{tabular}{lrrrr}
\hline \multicolumn{5}{c}{ Model Summary } \\
\hline Model & $\mathrm{R}$ & $\begin{array}{c}\mathrm{R} \\
\text { Square }\end{array}$ & $\begin{array}{c}\text { Adjusted R } \\
\text { Square }\end{array}$ & $\begin{array}{c}\text { Std. Error } \\
\text { of the } \\
\text { Estimate }\end{array}$ \\
$\mathbf{1}$ &, 985 &, 971 &, 968 &, 07892
\end{tabular}

\section{a. Predictors: (Constant), ekonomis, efektif, efisien \\ Sumber: Hasil Koefesien Determinasi Menggunakan Program SPSS 21}

Hasil perhitungan menunjukan bahwa persentase pengaruh variabel independen (efektif (X1), efisien (X2), ekonomis (X3) dalam anggaran berbasis kinerja) terhadap variabel dependen yaitu efektivitas pengendalian anggaran sebesar 97,1 \% sedangkan 2,9\% lainnya dipengaruhi oleh variabel lain yang tidak diteliti.

\section{PEMBAHASAN ANTAR VARIABLE} Pengaruh Efektif Terhadap Efektivitas Pengendalian Anggaran di Dinas Pendapatan Dan Pengelolaan Keuangan dan Aset Daerah Kabupaten Bandung Barat

Koefisien regresi dimensi efektif $\left(X_{1}\right)$ sebesar 0,192 artinya jika variabel independen lain nilainya tetap dan efektif mengalami kenaikan 1\%, maka efektivitas pengendalian anggaran akan mengalami kenaikan sebesar 0,192 . Koefisien dalam regresi variabel efektif $\left(X_{1}\right)$ bernilai positif artinya terjadi hubungan positif antara efektif dengan efektivitas pengendalian anggaran. Apabila efektif meningkat maka efektivitas pengendalian anggaranpun akan ikut meningkat.

Kemudian secara parsial pengujian efektif berpengaruh terhadap efektivitas pengendalian anggaran memperoleh nilai $t_{\text {hitung }}(2,503)>$ tabel $(2,042)$ pada taraf signifikansi $0.018<0.05$ maka $\mathrm{H}_{0}$ ditolak, hal ini berarti efisien secara parsial berpengaruh terhadap efektivitas pengendalian anggaran pada DPPKAD Kabupaten Bandung barat.

Hal ini sesuai dengan teori yang dikemukakan oleh Bastian (2005:24) bahwa upaya untuk menciptakan pengelolaan anggaran berbasis kinerja diharapkan akan mampu memenuhi berbagai tuntutan dan dan kebutuhan masyarakat, yaitu terbentuknya semangat desentralisasi, demokrasi, transparansi, dan akuntabilitas dalam proses penyelengaraan Pemerintah pada umumnya dan proses pada pengelolaan keuangan daerah pada khususnya. Artinya pengangaran berbasis kinerja mendukung efektivitas pengendalian anggaran keuangan daerah.

Merujuk pada pendapat Akhmad Syakhroza (2004) mengatakan pencapaian target anggaran memainkan peranan penting karena anggaran menggambarkan standar efektifitas dan efisiensi. Anggaran menggambarkan standar efektifitas karena memuat suatu set pengeluaran yang diinginkan. Dalam rangka mencapai tujuan itu, organisasi sektor publik sering kali tidak memperhatikan biaya yang dikeluarkan. Hal tersebut sesuai dengan permasalahan yang terjadi di DPPKAD Bandung Barat bahwa penggunaan alokasi anggaran yang tidak terealisasikan dengan optimal sesuai dengan rencana alokasi anggaran yang telah direncanakan sebelumnya. Ini disebabkan oleh ketidakefektifannya pengelolaan dan PUBLISIA (Jurnal Ilmu Administrasi Publik) | 83 
penggunaan anggaran oleh DPPKAD Bandung Barat dengan seperti itu akan berpengaruh terhadap efektivitas pengendalian anggaran pada DPPKAD Bandung Barat. Agar pengeluaran actual sejalan dengan jumlah yang dianggarkan maka dalam penganggaran harus efektif.

Efektif berpengaruh terhadap efektifitas pengendalian anggaran jika anggaran dilakukan secara efektif, dalam artian anggaran yang efektif adalah anggaran yang ditargetkan sama dengan anggaran yang terrealisasikan. Sedangkan efektifitas pengendalian anggaran itu merupakan pengawasaan terhadap pengeluaran (output) maupun pendapatan (input) sehingga mencapai tujuan yang telah ditentukan. Oleh karena itu anggaran yang efektif merupakan output (hasil) yang harus dicapai dengan target yang sudah di rencanakan. Artinya jika anggaran tersebut tidak efektif maka dalam pengendalian anggaran kurang optimal atau kurang baik.

Berdasarkan penelitian yang dilakukan oleh Kharisma (2001) tentang "Pengaruh Efektivitas Anggaran Berbasis Kinerja Terhadap Efektivitas Pengendalian Anggaran Sensus Di Dinas-Dinas Kota Bandung" menyatakan bahwa terdapat pengaruh antara penerapan anggaran berbasis kinerja terhadap efektivitas pengendalian anggaran sensus di Dinas-dinas Kota Bandung. Hasil tersebut serupa dengan hasil penelitian ini, dimana efektif berpengaruh secara parsial terhadap efektivitas pengendalian anggaran di DPPKAD Bandung Barat.

\section{Pengaruh Proses Efisien Terhadap Efektivitas Pengendalian Anggaran di DPPKAD Kabupaten Bandung Barat}

Koefisien regresi dimensi efesien $\left(\mathrm{X}_{2}\right)$ sebesar 0,370artinya jika variabel independen lain nilainya tetap dan efesien mengalami kenaikan 1\%, maka efektivitas pengendalian anggaran akan mengalami kenaikan 0,370 .
Koefisien regresi variabel efesien $\left(X_{2}\right)$ bernilai positif artinya terjadi hubungan positif antara efesien dengan efektivitas pengendalian anggaran, dimana apabila efesien meningkat maka efektivitas pengendalian anggaran akan meningkat pula.

Kemudian secara parsial pengujian efisien berpengaruh terhadap efektivitas pengendalian anggaran memperoleh nilai thitung $(3,031)>t_{\text {tabel }}(2,042)$ pada taraf signifikansi $0.005<0.05$ maka $\mathrm{H}_{0}$ ditolak, hal ini berarti efisien secara parsial berpengaruh terhadap efektivitas pengendalian anggaran pada DPPKAD Kabupaten Bandung barat.

Merujuk pada pendapat Akhmad Syakhroza (2004) mengatakan pencapaian target anggaran memainkan peranan penting karena anggaran menggambarkan standar efektifitas dan efisiensi. Anggaran menggambarkan efisien karena anggaran memerinci masukan yang diperlukan untuk menghasilkan pengeluaran yang diingikan. Teori yang disampaikan bastian (2010:61) bahwa efisien merupakan hal terpenting dalam suatu organisasi. Artinya suatu organisasi dianggap semakin efisien apabila rasio efisien cenderung diatas satu. Apabila hasil rasio lebih besar dari satu dibandingkan hasil rasio program yang sama, program tersebut bisa disebut lebih efesien. Dalam konteks pengendalian anggaran bahwa tingkat efisiensi merupakan perbandingan antara output dan input. Semakin besar kontribusi output yang dhasilkan terhadap pencapaian tujuan atau sasaran yang ditentukan, maka semakin efektif proses kerja suatu unit di DPPKAD Kabupaten Bandung Barat. Hal ini tidak terlepas dari indikator efisien dan efektivitas yang harus digunakan secara bersama-sama. Karena disatu pihak, pelaksanaannya sudah dilakukan secara ekonomis dan efesien akan tetapi output yang dihasilkan tidak sesuai dengan target yang diharapkan. 
Efisien berpengaruh terhadap efektivitas pengendalian anggaran. jika anggaran dilakukan dengan efisien maka dapat diartikan dalam efektivitas pengendalian anggarannya baik. Dalam artian anggaran yang efisien adalah bagaimana menghasilkan target anggaran yang akan dicapai namun terrealisasi semaksimal mungkin dengan anggaran yang ada. Efektivitas pengendalian anggaran adalah pengawasaan terhadap pengeluaran dan pendapatan supaya mencapai target sesuai dengan rencana yang telah ditentukan. Efisien merupakan dari input (pendapatan) dan menghasilkan output yang maksimal.

Berdasarkan penelitian yang dilakukan oleh Kharisma (2011) tentang "Pengaruh Efektivitas Anggaran Berbasis Kinerja Terhadap Efektivitas Pengendalian Anggaran Sensus Di Dinas-Dinas Kota Bandung" menyatakan bahwa terdapat pengaruh antara penerapan anggaran berbasis kinerja terhadap efektivitas pengendalian anggaran sensus di Dinas-dinas Kota Bandung. Hasil tersebut serupa dengan hasil penelitian ini, dimana efesien berpengaruh secara parsial terhadap efektivitas pengendalian anggaran di DPPKAD Bandung Barat.

Pengaruh ekonomis terhadap efektivitas Pengendalian Anggaran di Dinas Pendapatan Dan Pengelolaan Keuangan Dan Aset Daerah Kabupaten Bandung Barat

Koefisien regresi dimensi ekonomis $\left(\mathrm{X}_{3}\right)$ sebesar 0,422 artinya jika variabel independen lain nilainya tetap dan ekonomis mengalami kenaikan 1\%, maka efektivitas pengendalian anggaran akan mengalami kenaikan 0,422. Koefisien regresi variabel ekonomis $\left(\mathrm{X}_{3}\right)$ bernilai positif artinya terjadi hubungan positif antara ekonomis dengan efektivitas pengendalian anggaran, dimana apabila ekonomis meningkat maka efektivitas pengendalian anggaran akan meningkat pula.
Kemudian secara parsial pengujian ekonomis berpengaruh terhadap efektivitas pengendalian anggaran memperoleh nilai $t_{\text {hitung }}(3,806)>t_{\text {tabel }}(2,042)$ pada taraf signifikansi $0.001<0.05$ maka $\mathrm{H}_{0}$ ditolak, hal ini berarti ekonomis secara parsial berpengaruh terhadap efektivitas pengendalian anggaran pada DPPKAD Kabupaten Bandung barat. Jadi, secara empiris hasil tersebut dapat menjelaskan bahwa hipotesis awal yang diajukan sesuai dengan hasil penelitian yang dilakukan.

Dimensi ekonomis dalam anggaran berbasis kinerja berpengaruh terhadap efektivitas pengendalian anggaran. Hal ini sesuai dengan teori Bastian (2010:61) pada dasarnya ekonomis lebih kepada input. Artinya suatu pengendalian, pengelolaan dan pengeluaran anggaran itu dapat dikatakan efektif apabila dalam penganggaran memperhatikan nilai ekonomis. Jika kita melihat permasalahan yang terjadi pada Dinas Pendapatan dan Pengelolaan Keuangan dan Aset Daerah Kabupaten Bandung Barat efektivitas pengendalian anggaran dalam pencapaian targetnya kurang baik hal ini salah satunya disebabkan karena dalam penyusunan anggaranya tidak ekonomis oleh karena itu supaya pemasukan dan pengeluaran seimbang atau sejalan sesuai dengan target maka nilai ekonomis dalam pengannggaran harus diperhatikan.

Ekonomis berpengaruh dengan efektivitas pengendalian anggaran jika anggaran dilakukan secara ekonomis, dalam artian ekonomis itu Dinas Pendapatan dan Pengelolaan Keuangan dan Aset Daerah mampu menggunakan anggaran dari pemerintah semaksimal mungkin dengan dana yang ada. Efektivitas pengendalian anggaran merupakan pengawasan terhadap pengeluaran (output) maupun pendapatan (input). Disini ekonomis itu merupakan dari input. Jika input nya tidak ekonomis maka 
efektivitas pengendaliannya pun tidak akan tercapai dengan baik.

Berdasarkan penelitian yang dilakukan oleh Kharisma (2011) tentang "Pengaruh Efektivitas Anggaran Berbasis Kinerja Terhadap Efektivitas Pengendalian Anggaran Sensus Di Dinas-Dinas Kota Bandung" menyatakan bahwa terdapat pengaruh antara penerapan anggaran berbasis kinerja terhadap efektivitas pengendalian anggaran sensus di Dinas-dinas Kota Bandung. Hasil tersebut serupa dengan hasil penelitian ini, dimana ekonomis berpengaruh secara parsial terhadap efektivitas pengendalian anggaran di DPPKAD Bandung Barat.

\section{Pengaruh efektif, efisien dan ekonomis terhadap efektivitas pengendalian anggaran di DPPKAD Kabupaten Bandung Barat}

Hasil koefisien regresi dari efektif $\left(0,192 X_{1}\right)$, efisien $\left(0,370 \mathrm{X}_{2}\right)$, ekonomis $(0,422$ $\mathrm{X}_{3}$ ) dalam anggaran berbasis kinerja secara bersama-sama menunjukan nilai yang positif. Kemudian, konstanta Y (efektivitas pengendalian anggaran) memiliki koefisien regresi sebesar 0,078. Artinya: " jika dimensi efektif $\left(X_{1}\right)$, efisien $\left(X_{2}\right)$ dan ekonomis $\left(X_{3}\right)$ nilainya adalah 0 , maka efektivitas pengendalian anggaran $(\mathrm{Y})$ nilainya adalah 0,078 ".

Kemudian, secara simultan pengujian dimensi efektif, efisien, dan ekonomis dalam anggaran berbasis kinerja berpengaruh terhadap efektivitas pengendalian anggaran memperoleh nilai $F_{\text {hitung }}(321,772)>\mathrm{F}_{\text {tabel }}(3,30)$ dengan taraf signifikansi $0.000<0.05$ maka $\mathrm{H}_{0}$ ditolak, hal ini berarti efektif, efisien, dan ekonomis dalam anggaran berbasis kinerja berpengaruh secara simultan terhadap Efektivitas Pengendalian Anggran pada Dinas Pendapatan dan Pengelolaan Keuangan dan Aset daerah Kabupaten Bandung Barat. Dengan R square 0,971 yang berarti pengaruh Anggaran Berbasis Kinerja terhadap Efektivitas Pengendalian Anggaran adalah sebesar 97,1 \% sedangkan sisanya dipengaruhi oleh variabel lain yang tidak diteliti. Jadi, secara empiris hasil tersebut dapat menjelaskan bahwa hipotesis awal yang diajukan sesuai dengan hasil penelitian yang dilakukan.

Hasil penelitian ini sejalan dengan teori dari Anggarini dan Puanto (2010:99) yang menyatakan bahwa sistem penganggaran berbasis kinerja merupakan suatu sistem penyusunan anggaran yang menekankan pada hasil dan mengendalikan belanja. Sistem ini terutama berusaha untuk mengaitkan langsung antara keluaran (outputs) dengan hasil (outcomes) yang disertai dengan penekanan terhadap efektivitas dan efesiensi anggaran yang dialokasikan. Hasil ini juga membuktikan teori dari Jones dan pendlebury dalam Sabeni (200:115) menjelaskan bahwa anggaran menyediakan hubungan penting antara perencanaan dan pengendalian. Oleh karena itu anggaran berbasis kinerja disusun untuk mengatasi berbagai kelemahan yang terdapat dalam anggaran tradisional, khususnya kelemahan yang disebabkan oleh tidak adanya tolak ukur yang dapat digunakan untuk mengukur kinerja dalam pencapaian tujuan dan sasaran pelayanan publik DPPKAD Kabupaten Bandung Barat. Dengan demikian dapat dikatakan bahwa penyusunan anggaran yang berbasis kinerja di DPPKAD Kabupaten Bandung Barat diharapkan menghasilkan anggaran yang lebih berkualitas sehingga lebih efektif dalam pengendaliannya.

Hasil penelitian ini juga mendukung berbagai penelitian terdahulu yang pernah dilakukan oleh Kharisma (2011) yang menyatakan bahwa terdapat pengaruh antara penerapan anggaran berbasis kinerja terhadap efektivitas pengendalian anggaran sensus di Dinas-dinas Kota Bandung. Selanjutnya penelitian Asmoko (2006) yang menyatakan bahwa penggaran berbasis kinerja berpengaruh positif secara signifikan 
terhadap efektivitas pengendalian anggaran pada Dinas Pertanian dan Ketahanan Pangan Provinsi Gorontalo. Kedua hasil tersebut nampak berbanding lurus dengan penelitian yang dilakukan dimana, anggaran berbasis kinerja berpengaruh secara positif dan simultan terhadap efektivitas pengendalian anggaran pada DPPKAD Kabupaten Bandung Barat.

\section{KESIMPULAN}

Berdasarkan pembahasan di atas maka jelaslah bahwa kontribusi anggaran berbasis kinerja sangatlah tinggi dalam pencapain efektifitas pengendalian anggaran. Seorang pengendali organisasi dalam hal ini pimpinan harus memperhatikan aspek anggaran berbasis kinerja berikut dimensi-dimensinya. Sehingga kehidupan organisasi dapat terjaga dengan baik, karena anggaran yang ditetapkan oleh organisasi berbasis system yang efektif, efesien dan ekonomis. Dimensi efektif, efesien dan ekonomis dalam analisisis berbasis kinerja berpengaruh secara parsial dan simultan terhadap efektifitas pengendalian anggaran pada DPPKAD Kabupaten Bandung Barat.

Penelitian ini banyak memiliki keterbatasan dalam pelaksanaannya, sehingga perlu dilakukan beberapa perbaikan dalam meningkatkan efektifitas pengendalian anggaran. Diantaranya peneliti harus melaksanakan penelitian tidak terfokus pada satu instansi namun mengikutsertakan banyak instansi sehingga hasil penelitian dapat digeneralisis untuk kepentingan bersama. Selain itu, penelitian ini menitikberaktkan pada asumsi sikap pegawai terhadap pelaporan keuangan dengan kata lain hanya terfokus pada sikap dan persepsi yang dikumpulkan lewat kuesioner yang seharusnya peneliti juga harus mempertimbangkan aspek-aspek lain seperti eksperimen dalam pelaksanaan pengumpulan data. Sehingga banyak sumber yang dapat dijadikan sebagai rujukan.

\section{DAFTAR PUSTAKA}

Akhmad Syakhroza "Model Komisaris untuk Efektifitas GCG di Indonesia", Usahawan No. 05, Mei 2004

Alwi, Hasan. 2007. KBBI, edisi ketiga. Jakarta: Balai Pustaka.

Arikunto, Suharismi. 2006. Prosedur Penelitian Suatu Pendekatan Praktik. Jakarta: Rineka Cipta.

Anggara, Sahya. 2012. Ilmu Administrasi Negara: Kajian Konsep, Teori, dan Fakta Dalam Upaya Menciptakan Good Governance. Bandung: Pustaka Setia.

Bastian, Indra. 2010. Akuntansi Sektor Publik Suatu Pengantar. Yogyakarta: Erlangga.

Cooper, Donald R \& Schindler, Pamela S. 2003, "Bussines Research Methods", 9th edition. McGraw-Hill International Edition

Fahmi, Irham. 2011. Manajemen Kinerja Teori dan Aplikasi. Bandung: Alfabeta.

Ghozali, Imam. 2005. Aplikasi Analisis Multivariate dengan program SPSS, Badan Penerbit Universitas Diponegoro. Semarang.

Gibson, James. L, et all. 1995. Organisasi, Perilaku, Struktur, Proses. Edisi ke-5. Jakarta : Erlangga.

Halim, Abdul. 2014. Manajemen Keuangan Sektor Publik; Problematika Penerimanaan dan Pengeluaran Pemerintah. Jakarta: Salemba Empat.

Hair, F. Joseph JR. Rolp E. Andersen, Ronald L Tatham dan William C. Black (1998). Multivariate Data Analysis, fifth edition, New Jersey: Prantice Hall

Hasan, Iqbal. 2006. Analisis Data Penelitian Dengan Statistik. Jakarta: PT. Bumi Aksara. 
Jones, R dan M. Pendlebury. 2000. Public Sector Accounting. 5th Edition. Pitman Publishing, London

Kharisma, 2011. Pengaruh penerapan anggaran berbasis kinerja terhadap efektifitas pengendalian.

Mahmudi, 2015. Manajemen Kinerja Sektor Publik. Yogyakarta: UPP STIM YKPN.

Maman Ukas. 2004, "Manajemen Konsep, Prinsip Dan Aplikasi", Cetakan ketiga, Agnini Bandung

Mardiasmo. 2009. Akuntansi Sektor Publik. Yogyakarta: ANDI.

Mardiasmo. Akuntansi Sektor Publik (Yogyakarta: Andi, 2009)

Munawir. 1992. Analisis Laporan Keuangan edisi Pertama cetakan Pertama. Yogyakarta: Liberty

Robinson, M and Brumby, J. 2005. Does Performance-Based Budgeting Work?: AnAnalytical Review of the Empirical Literature. IMF Working Paper 05/210.International Monetary Fund. Washington.

Shah, A dan Shen, C. 2007. Citizen-Centric performance Budgeting at the local Level. Public Sector and Govermance and Acountability Series: Local Budgeting. World Bank.

Singarimbun, dan Effendi, 2003. Metode Penelitian Survey, Cetakan Kedua, PenerbitPT. Pustaka LP3ES Indonesia, Jakarta.

Sonny Sumarsono. 2010. Manajemen Keuangan Pemerintahan. Yogyakarta: Graha Ilmu

Sugiyono. 2013. Metode Penelitian Admnistrasi. Bandung: Alfabeta

Umar, Husein. 2003, Metode Riset Akuntansi Terapan, Jakarta: Ghalia Indonesia, Cetakan Pertama 